\title{
Establishment year productivity, botanical composition and nutritive value of grass/lucerne/plantain dairy pasture mixtures
}

M.B. DODD ${ }^{1,3}$, D.E. DALLEY ${ }^{2}$, D. ELLIOTT ${ }^{1}$ and C.M. WIMS ${ }^{1}$

${ }^{l}$ DairyNZ Ltd, Private Bag 3221, Hamilton 3240, New Zealand

${ }^{2}$ DairyNZ Ltd, Canterbury Agricultural and Science Centre, Lincoln 7608, New Zealand ${ }^{3}$ AgResearch Ltd, Grasslands Research Centre, Private Bag 11008, Palmerston North 4442, New Zealand mike.dodd@dairynz.co.nz

\section{Abstract}

In the context of dairy grazing systems, pasture mixtures including tall fescue, lucerne and plantain have been identified by animal modelling as having potential to both improve milk production and reduce urinary nitrogen excretion. A grazed paddock-scale trial was established in the Waikato in September 2015 to test this in two short-term grazing trials including these species. This paper presents the pasture production, botanical composition and nutritive value data generated from four pasture mixtures sown in spring 2015 and sampled until autumn 2017 (18 months). The pasture mixtures represented a comparison between perennial ryegrass and tall fescue, with and without the herb narrow-leaved plantain. The inclusion of plantain in grass-lucerne mixtures had a positive effect on firstyear herbage dry matter (DM) production, by $\sim 2.6 \mathrm{t}$ $\mathrm{DM} /$ ha/year in ryegrass-based pastures and $\sim 1.6 \mathrm{t} \mathrm{DM} /$ ha/year in tall fescue-based pastures. Where plantain was included, the proportion of grass was reduced by more than half from autumn 2016 through to summer 2016-2017, while the proportion of lucerne was reduced to a lesser degree. The proportion of plantain was $35-70 \%$ through most of the first year, declining to $<20 \%$ in the second autumn. Plantain pastures had slightly less crude protein (CP \%) in winter, but the inclusion of plantain did not significantly affect digestibility or metabolisable energy in any season. Given the evidence from other studies that plantain can reduce urinary nitrogen concentration in dairy cows, this study indicates that it can be a useful component in mixed pastures from a forage production and nutritive value perspective.

Keywords: nitrogen, pasture production, narrowleaved plantain, perennial ryegrass, tall fescue

\section{Introduction}

The Forages for Reduced Nitrate Leaching (FRNL) Programme is a 6-year study investigating how a range of forages can be used within modern grazing systems to both improve animal production and reduce urinary nitrogen $(\mathrm{N})$ excretion. One of the major aims of the programme is to determine whether novel pasture species mixtures can contribute to this goal, by including range of species in diverse pastures to see whether hey reduce uring $\mathrm{N}$ output from cows, rather than looking at individual forage species in monocultures.

When plant attributes are combined in a multi-species pasture, the mixtures typically have greater annual herbage production than conventional grass-clover pastures (e. Moloney 1991: Sanderson et al. 2005; hough not ways (e.g. Woodward et al. 2013 achieve greater total annual nitrogen $(\mathrm{N})$ uptake due to their complementary root systems and seasonal growth patterns (Vibart et al. 2016). In New Zealand, the early interest in using diverse pasture mixtures arose from a need to maintain animal production in environments where conventional perennial ryegrass/white clover pastures showed poor forage supply and persistence per Cichorich (Cichorium intybus) and narrow-leaved plantain (Plantago lanceolata) were used as they had already shown promise in monoculture; good quality seed was available and their management was well understood.

It is important to know whether the benefits of diverse pastures can be attributed to the greater diversity of species in the pasture mixture or to the presence of individual species. Pembleton et al. (2015) chenefits to the functional attributes of he additional species and Vibart et al. (2016) also suggested that the presence of specific well-adapted species is more important than the number of species, in driving herbage production and $\mathrm{N}$ dynamics. There is now good evidence from New Zealand studies of dairy systems that pasture mixtures containing forage herbs, in particular narrow-leaved plantain, lead to reductions in urinary $\mathrm{N}$ concentration (Table 1). In some cases, this has also resulted in improvements in milksolids (MS) production.

Given that much of the work on this subject to date has been conducted in Canterbury, a grazed paddockscale trial was established in the Waikato in September 2015 to examine the effect of specific pasture mixtures on milk production and urinary $\mathrm{N}$ in two short-term grazing trials. The results of these grazing trials in 
February 2016 and November 2016 will be presented lsewhere (see Dodd et al. 2017). The objective of this paper is to document the early development of the pasture mixtures in terms of seasonal herbage production, botanical composition, and nutritive value

\section{Methods}

Selection of swards

The pasture species selected for this field experiment were based on simulations with the MOLLY animal model, using data on chemical composition and metabolisable energy for a range of pasture species (Gregorini et al. 2016). The modelling compare perennial ryegrass (Lolium perenne), tall fescue (Festuca arundinacea), cocksfoot (Dactylis glomerata), kikuyu (Pennisetum clandestinum), prairie grass (Bromus willdenowii), white clover (Trifolium repens) lucerne (Medicago sativa), red clover (Trifolium pratense), lotus (Lotus pedunculatus), chicory and plantain, in 72 simulated combinations. Combinations of tall fescue, lucerne and plantain were predicted to maximise the ratio of MS to urinary nitrogen. These key species were then used in field experiments that was designed to compare the effect of a) the base grass species (perennial ryegrass versus tall fescue) and $b$ ) the presence or absence of plantain.

\section{Pasture establishment}

Four different pasture species combinations were established at the DairyNZ Scott Farm in October 2015 (Lat. - 37.766, Long. 175.364). Table 2 shows the combinations of perennial ryegrass (PR), tall fescue
(TF), lucerne (L) and plantain (P) used, along with cultivar, sowing rate and endophyte details. The sowing rates were chosen to achieve a grass:legume:herb ratio of 60:40:0 or 60:20:20, recognising the known cultivar differences in seed size and establishment rate. Each treatment included six replicate paddocks of 0.5 ha. Five replicates were located on a Matangi silt loam soil type (Typic Orthic Gley, Hewitt 1992) with one replicate of each treatment located on a Te Rapa Humic silt loam (Orthic Podzol, Hewitt 1992).

All paddocks were individually soil sampled on 8 September 2015 to a depth of $150 \mathrm{~mm}$, taking 20 samples per paddock and analysing each paddock for $\mathrm{pH}$, major nutrients, and cations ("MAF Quicktest", Cornforth \& Sinclair 1984). Lime was applied to each paddock in late September 2015 at rates of 2-6 t/ha, as per requirements based on soil $\mathrm{pH}$ measurements. Phosphorus and potassium were applied to all paddocks as Superten ${ }^{\mathrm{TM}}+\mathrm{K}$ in late September 2015 at ates of 0-54 $\mathrm{kg}$ P/ha and $0-500 \mathrm{~kg} \mathrm{~K} / \mathrm{ha}$, as per requirements based on the soil test results. Pasture establishment commenced on 9 September 2015 by application of herbicide (1960 g/ ha glyphosate $+24 \mathrm{~g} /$ ha cafentrazone-ethyl) to existing perennial ryegrass/white clover pastures. The paddocks were then ploughed in late September, followed by a further application of $980 \mathrm{~g} / \mathrm{ha}$ glyphosate $+240 \mathrm{~g} / \mathrm{ha}$ diazinon in early October, power harrowing and rolling in late October. Sowing date was 28 Octob

\section{Pasture management}

Nitrogen fertiliser was applied to all paddocks monthly at rates of $45-80 \mathrm{~kg} \mathrm{~N} / \mathrm{ha}$. Herbicides were used as
Table 1 Summary of recent New Zealand experiments examining the effect of various pasture mixes in comparison with conventional ryegrass/white clover swards, on dairy cow milksolids (MS) production and urinary nitrogen (UN)
concentration. Statistically significant effects were quantified.

\begin{tabular}{|c|c|c|c|}
\hline $\begin{array}{l}\text { Pasture type compared } \\
\text { with ryegrass/white clover }\end{array}$ & Season & $\begin{array}{l}\text { Change in MS yield } \\
(\mathrm{kg} \mathrm{MS} / \mathrm{cow} / \mathrm{d})\end{array}$ & $\begin{array}{c}\text { Change in UN } \\
\text { concentration }(\mathrm{g} \mathrm{N} / \mathrm{L})\end{array}$ \\
\hline Ryegrass + white clover + chicory + plantain ${ }^{1}$ & Autumn & Nil & $-40 \%(5.7$ versus 3.4$)$ \\
\hline Ryegrass + white clover + chicory + plantain + lucerne ${ }^{2}$ & Spring & Nil & $-20 \%(6.1$ versus 4.9$)$ \\
\hline Ryegrass + white clover + prairie grass & Spring & Nil & $-30 \%(4.2$ versus 2.9$)$ \\
\hline \multirow[t]{2}{*}{+ chicory + plantain + red clover ${ }^{3}$} & Summer & $+17 \%(1.47$ versus 1.72$)$ & Nil \\
\hline & Autumn & Nil & Nil \\
\hline Ryegrass $^{*}+$ white clover + prairie grass & Spring & Nil & $-28 \%(4.6$ versus 3.3$)$ \\
\hline \multirow[t]{2}{*}{+ chicory +plantain +red clover ${ }^{3}$} & Summer & Nil & $-28 \%(4.4$ versus 3.1$)$ \\
\hline & Autumn & Nil & $-22 \%(6.8$ versus 5.3$)$ \\
\hline Plantain ${ }^{4}$ & Autumn & $+11 \%(1.50$ versus 1.67$)$ & $-56 \%(5.4$ versus 2.4$)$ \\
\hline Ryegrass + white clover + plantain 4 & Autumn & $+7 \%(1.50$ versus 1.60$)$ & $-33 \%(5.4$ versus 3.6$)$ \\
\hline
\end{tabular}

Totty et al. (2013); ' Edwards et al. (2015); ${ }^{3}$ Bryant et al. (2017); ${ }^{4}$ (Box et al. 2016).
"comparison using high sugar ryegrass. required to control dicotyledonous weeds. Non-plantain paddocks were sprayed with $2.5 \mathrm{~L} / \mathrm{ha} \operatorname{Dynamo}^{\circledR}$ (a.i. 17 $\mathrm{g} / \mathrm{L}$ flumetsulam $+480 \mathrm{~g} / \mathrm{L}$ bentazone), and plantain paddocks with $2.5 \mathrm{~L} / \mathrm{ha}$ of Dictate ${ }^{\circledR}$ (a.i. $480 \mathrm{~g} / \mathrm{L}$ bentazone) in November 2015. Infestations of plantain moth were controlled by application of $150 \mathrm{ml} / \mathrm{ha}$ of Exirel $^{\circledR}$ (a.i. $150 \mathrm{~g} / \mathrm{L}$ cyantraniliprole) in April 2016.

During the period before, in between and after

the two grazing experiments the paddocks were the two grazing experiments the paddocks were rotationally grazed with a mixed-aged herd of dairy $\mathrm{kg} \mathrm{DM} / \mathrm{ha}$ and post-graze target covers of $1500-1600$ $\mathrm{kg} \mathrm{DM/ha}$ and post-graze target covers or 1500-1600 $\mathrm{kg} \mathrm{DM} / \mathrm{ha}$. Grazing intervals were between 28-63 days depending on seasonal growth rates. All paddocks were re-allocated to other research projects in February 2017 (non-plantain paddocks) or June 2017 (plantain paddocks), thus ending the data record.

\section{Pasture measurement}

Four plots of $10 \times 1.5 \mathrm{~m}$ in each paddock were harvested before each grazing, with a Haldrup mower (model F-55, Haldrup a/s, Denmark) to $4.5 \mathrm{~cm}$ height. The harvested herbage was weighed fresh, well mixed and three $100 \mathrm{~g}$ subsamples taken for DM determination (dry weights determined after 48 hours at $95^{\circ} \mathrm{C}$ ). At least once within each season (defined by the DairyNZ Forage Value Index, Chapman et al. 2016), an additional $100 \mathrm{~g}$ subsample was taken for dissection into component species (all sown species and bulked unsown species) which were also dried and weighed. From herbage harvested from each paddock in February, May, September and November 2016 and January 2017, an additional $150 \mathrm{~g}$ fresh subsample was dried at $60^{\circ} \mathrm{C}$, ground and analysed by NIRS (Hill Laboratories, Hamilton, New Zealand) for crude protein (CP), metabolisable energy (ME) and digestibility of organic matter in DM (DOMD).

\section{Statistical analysis}

The statistical analysis of DM, botanical composition and pasture quality data with ANOVA followed a $2 \times 2$ factorial design (the main factors were base pasture gras species and the absence/presence of plantain). Sampling dates were allocated to seasons according to the DairyNZ Forage Value Index and herbage accumulation data were applied pro-rata by the number of days where harvest intervals crossed seasonal boundaries.

\section{Results and Discussion}

\section{rbage accumulation}

Herbage production was greater in the ryegrass-based pastures during the first summer $(\mathrm{P}<0.05$, Table 3$)$, the following winter $(\mathrm{P}<0.05)$ and late spring $(\mathrm{P}<0.01)$. These seasonal differences are consistent with the well-recognised establishment rates and relative seasonal growth patterns of PR and TF (Clark et al. 2010). Over a full year of pasture havests (Feb 2016 the total herbage production of the ryegrass and fescuebased pastures. However, over that full year, the paddocks with plantain grew on average $2.6 \mathrm{t} \mathrm{DM}$ ha (for ryegrass-based pastures) or $1.6 \mathrm{t} \mathrm{DM} / \mathrm{ha}$ (for fescue-based pastures) more forage in total than those without plantain $(\mathrm{P}<0.01)$. The seasonal breakdown showed that this difference was most apparent during early $(\mathrm{P}<0.01)$ and late spring $(\mathrm{P}<0.05)$. No significant interactions were found between base grass species and plantain presence in terms of herbage DM production at any stage. While there are a number of previous studies showing increased DM production with the inclusion of plantain in mixed pastures, in such cases it has typically been a minor component with a number of other species (e.g. Daly et al. 1996; Nobilly et al. 2013). These results indicate the potential contribution of plantain as a major sward component.

Table 2 Sown species, cultivar, endophyte and sowing rate details of the four pasture type treatment combinations.

\begin{tabular}{|c|c|c|c|c|}
\hline $\begin{array}{l}\text { Pasture type } \\
\text { treatment }\end{array}$ & Base pasture grass & Endophyte & Legume & Herb \\
\hline$P R+L$ & $\begin{array}{l}\text { Perennial ryegrass cv. } \\
\text { Ceres One50 } \\
@ 18 \mathrm{~kg} / \mathrm{ha}\end{array}$ & AR37 & $\begin{array}{l}\text { Lucerne cv. } \\
\text { 'Grasslands Torlesse' } \\
\text { @ 6 6g/ha }\end{array}$ & Nil \\
\hline$P R+L+P$ & $\begin{array}{l}\text { Perennial ryegrass cv. } \\
\text { Ceres One50 } \\
@ 18 \mathrm{~kg} / \mathrm{ha}\end{array}$ & AR37 & $\begin{array}{c}\text { Lucerne cv. } \\
\text { 'Grasslands Torlesse' } \\
\text { @ } 5 \mathrm{~kg} / \mathrm{ha}\end{array}$ & $\begin{array}{r}\text { Plantain cv. } \\
\text { Ceres Tonic } \\
@ 2 \mathrm{~kg} / \mathrm{ha}\end{array}$ \\
\hline$T F+L$ & $\begin{array}{c}\text { Tall fescue cv. } \\
\text { 'Grasslands Hummer' } \\
@ 25 \mathrm{~kg} / \mathrm{ha}\end{array}$ & AR542 & $\begin{array}{c}\text { Lucerne cv. } \\
\text { 'Grasslands Torlesse' } \\
@ 6 \mathrm{~kg} / \mathrm{ha}\end{array}$ & $\mathrm{Nil}$ \\
\hline$T F+L+P$ & $\begin{array}{l}\text { Tall fescue cv. } \\
\text { 'Grasslands Hummer' } \\
\text { @ } 25 \mathrm{~kg} / \mathrm{ha}\end{array}$ & AR542 & $\begin{array}{l}\text { Lucerne cv. } \\
\text { 'Grasslands Torlesse' } \\
@ 5 \mathrm{~kg} / \mathrm{ha}\end{array}$ & $\begin{array}{l}\text { Plantain cv. } \\
\text { Ceres Tonic } \\
\text { @ } 1 \mathrm{~kg} / \mathrm{ha}\end{array}$ \\
\hline
\end{tabular}




\section{Botanical composition}

The contribution of ryegrass in the $\mathrm{PR}+\mathrm{L}$ swards was consistently greater than that of tall fescue in the $\mathrm{TF}+\mathrm{L}$ swards (Figure 1), although this was only significant in late spring $(\mathrm{P}<0.05)$. The grass contribution of both base grasses was diminished by more than half with the inclusion of plantain in all seasons $(\mathrm{P}<0.01)$. While the contribution of plantain was consistently less in tallfescue swards, this was not significant in any season. Lucerne contributed most to the swards in the second summer and autumn (Figure 1). In the winter and early spring the contribution of lucerne was less in ryegrass than in fescue-based pastures $(\mathrm{P}<0.05)$. While the contribution of lucerne was consistently greater where plantain was not present this effect was only significan

Table 3 Seasonal and annual herbage DM accumulation ( $\mathrm{DMM} / \mathrm{ha}$ ) of four pasture mixtures as measured by harvesting to a 4.5 $\mathrm{cm}$ stubble Seasons are as defined in the Dairy Z Forage Value index for the upper North Island1. PR = perennia ryegrass; $T F=$ tall fescue; $L=$ lucerne; $P$ = plantain; $S E D=$ standard error of difference; NS=not significant, $P>0.05$.

\begin{tabular}{lccccccc}
\hline Period & PR+L & PR+L+P & TF+L & TF+L+P & Treatment SED & Grass effect & Plantain effect \\
\hline Summer 2015 & 4.06 & 5.00 & 3.19 & 4.27 & 0.47 & $\mathrm{P}<0.05$ & $\mathrm{P}<0.01$ \\
Autumn 2016 & 2.78 & 3.57 & 3.13 & 3.43 & 0.45 & $\mathrm{NS}$ & $\mathrm{NS}$ \\
Winter 2016 & 1.40 & 1.37 & 0.99 & 1.36 & 0.14 & $\mathrm{P}<0.05$ & $\mathrm{NS}$ \\
Early Spring 2016 & 1.16 & 1.32 & 1.10 & 1.44 & 0.11 & $\mathrm{NS}$ & $\mathrm{P}<0.01$ \\
Late Spring 2016 & 2.50 & 3.27 & 2.11 & 2.35 & 0.27 & $\mathrm{P}<0.01$ & $\mathrm{P}<0.05$ \\
Summer 2016 & 3.93 & 4.83 & 3.83 & 4.23 & 0.45 & $\mathrm{NS}$ & $\mathrm{NS}$ \\
Autumn 2017 & & 3.93 & & 3.68 & 0.65 & & $\mathrm{NS}$ \\
Total annual $^{2}$ & 11.75 & 14.34 & 11.16 & 12.81 & 0.78 & $\mathrm{NS}$ & $\mathrm{P}<0.01$ \\
\hline
\end{tabular}

${ }^{1}$ Summer (Nov-Jan); Autumn (Feb-Apr); Winter (May-Jun); Early Spring (Jul-Aug); Late Spring (Sep-Oct);'Autumn 2016 - Summer 2016 inclusive.

Table 4 Seasonal herbage nutritive value of four pasture types. Seasons are as defined in the Dairy NZ Forage Value index for the upper North Island. $\mathrm{CP}=$ crude protein $(\%) ; \mathrm{DOMD}=$ digestibility of organic matter in dry matter $(\%) ; \mathrm{ME}=$ metabolisable energy $(M J M E / k g D M ; P R$
difference; $N S=$ pot significant, $P>0.05$.

\begin{tabular}{lcrrrrrrc}
\hline Season & Measure & PR+L & PR+L+P & TF+L & TF+L+P & SED & $\begin{array}{c}\text { Grass } \\
\text { effect }\end{array}$ & $\begin{array}{c}\text { Plantain } \\
\text { effect }\end{array}$ \\
\hline Autumn 2016 (Feb) & CP & 21.2 & 18.5 & 21.4 & 18.6 & 1.7 & NS & NS \\
& DOMD & 56.5 & 59.8 & 57.8 & 59.1 & 1.6 & NS & NS \\
& ME & 9.1 & 9.6 & 9.2 & 9.5 & 0.3 & NS & NS \\
\hline Winter 2016 (May-Jun) & CP & 25.5 & 23.4 & 30.0 & 23.7 & 1.6 & P $<0.05$ & P $<0.01$ \\
& DOMD & 71.7 & 72.7 & 73.9 & 73.1 & 1.2 & NS & NS \\
& ME & 11.5 & 11.6 & 11.8 & 11.7 & 0.2 & NS & NS \\
\hline Late Spring 2016 (Sep) & CP & 22.7 & 24.8 & 24.3 & 26.5 & 1.8 & NS & NS \\
& DOMD & 76.5 & 75.9 & 72.1 & 74.8 & 0.9 & P $<0.01$ & NS \\
& ME & 12.3 & 12.2 & 11.5 & 12.0 & 0.2 & $P<0.01$ & NS \\
\hline Summer 2016 (Nov) & CP & 17.4 & 17.2 & 18.8 & 20.3 & 1.5 & NS & NS \\
& DOMD & 69.3 & 69.2 & 66.9 & 67.2 & 0.8 & $\mathrm{P}<0.01$ & NS \\
& ME & 11.1 & 11.1 & 10.7 & 10.7 & 0.1 & $\mathrm{P}<0.01$ & NS \\
\hline
\end{tabular}

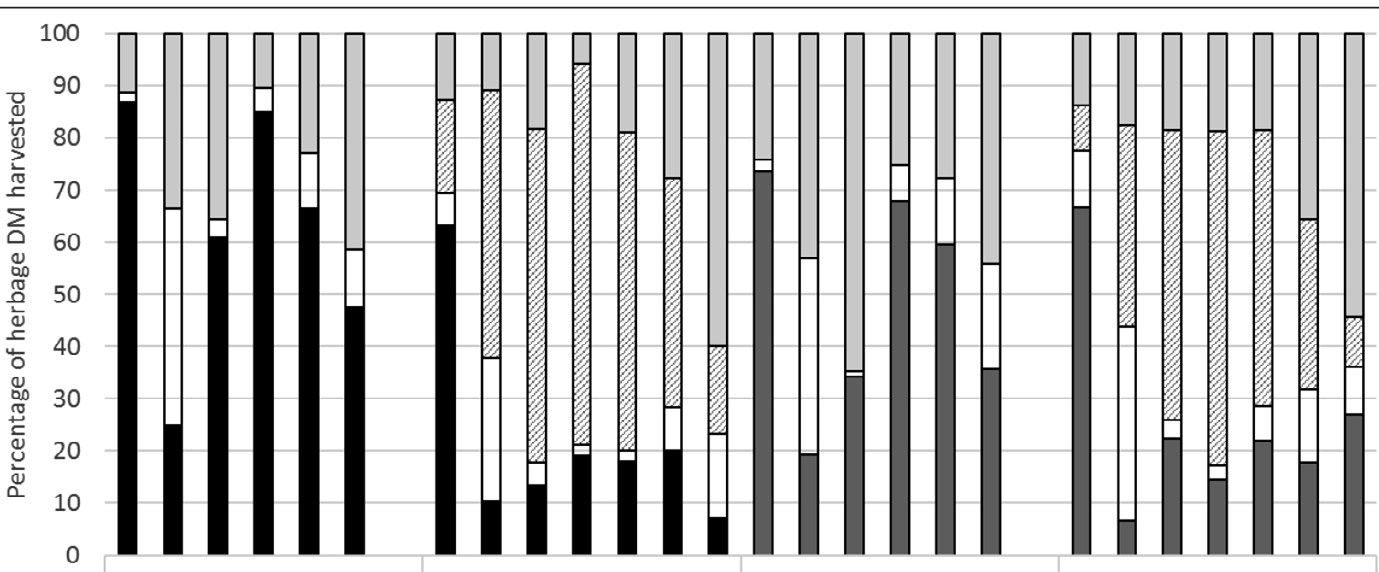

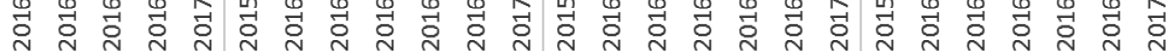

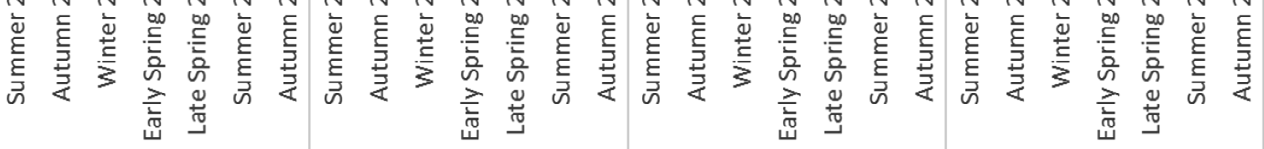

$P R+L$

$\mathrm{PR}+\mathrm{L}+\mathrm{P}$

Pasture type and seaso

$\mathrm{TF}+\mathrm{L}+\mathrm{P}$

- Perennial ryegrass aTall fescue aUnsown @Plantain aLucerne

Figure 1 Botanical composition of sown species in four pasture types from Summer 2016 to Autumn 2017, showing the percen contribution to DM yegrass; $\mathrm{TF}=$ tall fescue; $\mathrm{L}=$ lucerne; $\mathrm{P}=$ plantain

consistent with the $25 \mathrm{~cm}$ recommendation of Lee et al. (2015), grazing residuals were often much lower than the $8 \mathrm{~cm}$ recommended by Cranston et al. (2015). Typically, they were nearer $5 \mathrm{~cm}$ to suit the grass component, a level noted by Minneé et al. (2013) as being associated with a second-year decline in plantain productivity.

\section{Pasture quality}

Differences between the treatments for three key measures of pasture nutritive value (CP, DOMD, ME) over four seasons are shown in Table 4. Only in winter was $\mathrm{CP}$ lower where plantain was present $(\mathrm{P}<0.01)$. While plantain is known to contain lower $\mathrm{CP}$ than perennial ryegrass (Stewart 1996), this effect will also be a function of the reduction in lucerne content at that time (Figure 1). The presence of plantain did not significantly affect any of the quality parameters in other seasons. In terms of the overall feed value of the DM harvested, neither DOMD nor ME were at any time altered substantially by the inclusion of plantain in the swards. There were significant effects of the grass species in spring, with TF swards having lower DOMD and ME, which was particularly evident in late spring $(\mathrm{P}<0.01)$. This is possibly a reflection of differences in flowering dates of the cultivars used - Hummer TF being early heading and One50 PR being late heading.

\section{Conclusions}

Plantain was successfully established within perennial ryegrass and tall fescue dairy pastures sown during spring 2015 in the Waikato. Despite supressing the grass and legume components of the sward over the first 18 months of growth, plantain inclusion led to significant increases in DM yield in the first summer early and late spring periods, and over the whole first year. The nutritive value of the pastures was not substantially affected by the inclusion of plantain in any season during the first year. Given the evidence from various published studies, that including plantain in dairy cow diets leads to reduced urinary $\mathrm{N}$ excretion, this study indicates that its use as a major component of mixed pastures may have a positive effect on pasture production, with no loss of forage quality.

\section{ACKNOWLEDGEMENTS}

Thanks go to the DairyNZ technical team and Scott Farm eam for field work and experimental management, to Allister Moorhead and Ben Trotter (Agricom) for advice on pasture establishment, to Hill Laboratories for NIRS measurements and to Barbara Dow (DairyNZ) for statistical analysis. Research was completed as part of the Forages for Reduced Nitrate Leaching programme with principal funding from the New Zealand Ministry of 
Business, Innovation, and Employment. The programme is a partnership between DairyNZ, AgResearch, Plan \& Food Research, Lincoln University, Foundation for Arable Research and Landcare Research. The author acknowledge the contribution of the Journal reviewers to improving the paper.

\section{REFERENCES}

Ayala, W.; Barrios, E.; Bermudez, R.; Serrón, N. 2011 Effect of defoliation strategies on the productivity, population and morphology of plantain (Plantago lanceolata). Grassland Research and Practice Series 15: 73-77.

Box, L.A.; Edwards, G.R.; Bryant, R.H. 2016. Milk production and urinary nitrogen excretion of dairy cows grazing perennial ryegrass-white clover and pure plantain pastures. Proceedings of the New Zealand Society of Animal Production 76: 18-21.

Bryant, R.H.; Miller, M.E; Greenwood, S.L.; Edwards, G.R. 2017. Milk yield and nitrogen excretion of dairy cows grazing binary and multispecies pastures. Grass and Forage Science DOI: 10.1111/gfs.12274.

Chapman, D.F.; Bryant, J.R. Olayemi, M.E.; Edwards, G.R.; Thorrold, B.S.; McMillan, W.H.; Kerr, G.A.; Judson, G.; Cookson, T.; Moorhead A.; Norriss M. 2016. An economically based evaluation index for perennial and short-term ryegrasses in New Zealand dairy farm systems. Grass and Forage Science 72: $1-21$.

Clark, C.E.F.; Clark, D.A.; Waugh, C.D.; Roach, C.G.; Glassey, C.B.; Woodward, S.L.; Minneé, E.M.K. Woodfield, D.R. 2010. Systems to increase grazeable forage production in the Waikato: a progress repor on the tall fescue and perennial ryegrass component of these systems. Proceedings of the New Zealand Grassland Association 72: 49-54.

Cornforth, I.S.; Sinclair, A.G. 1984. Fertiliser and lime recommendations for pastures and crops in New Zealand. Second revised edition. Wellington: Ministry of Agriculture and Fisheries.

Cranston, L.M.; Kenyon, P.R.; Morris, S.T.; Kemp, P.D 2015. A review of the use of chicory, plantain, red clover and white clover in a sward mix for increase sheep and beef production. Journal of New Zealand Grasslands 77: 89-94.

Daly, M.J.; Hunter, R.M.; Green, G.N.; Hunt, L. 1996. A comparison of multi-species pasture with ryegrasswhite clover pasture under dryland conditions. Proceedings of the New Zealand Grassland Association 58: 53-58.

Dodd, M.; Dalley, D.; Bryant, R.; Welten, B.; Shorten, P. 2017. Pasture species mixtures to reduce nitrogen leaching. DairyNZ Technical Series \#34. https:// www.dairynz.co.nz/publications/technical-series/ technical-series-june-2017/ Accessed 19 July 2017. Edwards, G.R.; Bryant, R.H.; Smith, N.; Hague, H.; Taylor, S.; Ferris A.; Farrell L. 2015. Milk production and urination behaviour of dairy cows grazing diverse and simple pastures. Proceedings of the New Zealand Society of Animal Production 75: 79-83.

Gregorini, P.; Beukes, P.C.; Dalley, D.; Romera, A.J. 2016. Screening for diets that reduce urinary nitrogen excretion and methane emissions while maintaining or incering or increasing production by dairy : $32-41$

Hewitt, A.E. 1992. New Zealand Soil Classification. DSIR Land Resources Scientific Report No. 19. Department of Scientific and Industrial Research.

Lee, J.M.; Hemmingson, N.R.; Minneé, E.M.K.; Clark, C.E.F. 2015. Management strategies for chicory (Cichorium intybus) and plantain (Plantago lanceolata): impact on dry matter yield, nutritive characteristics and plant density. Crop and Pasture Science 66: 168-183.

Minneé, E.M.K.; Clark, C.E.F.; Clark, D.A. 2013. Herbage production from five grazable forages. Proceedings of the New Zealand Grassland Association 75: 245-250.

Moloney, S.C. 1991. Performance of tall fescue, cocksfoot and phalaris-based pastures, compared with perennial ryegrass, in on-farm trials. Proceedings of the New Zealand Grassland Association 53:41746. obilly, F.; Bryant, R.H.; McKenzie, B.A.; Edwards, G.R. 2013. Productivity of rotationally grazed simple and diverse pasture mixtures under irrigation in Canterbury. Proceedings of the New Zealand Grassland Association 75: 165-172.

Pembleton, K.G.; Tozer, K.N.; Edwards, G.R.; Jacobs, J.L.; Turner, L.R. 2015. Simple vs diverse pastures: opportunities and challenges in dairy systems. Animal Production Science 55: 893-901.

Sanderson, M.A.; Labreveux, M.; Hall, M.H.; Elwinger, G.F. 2003. Forage yield and persistence of chicory and English plantain. Crop Science 43: 995-1000.

anderson, M.A.; Soder, K.J.; Muller, L.D.; Klement, K.D.; Skinner, R.H.; Goslee, S.C. 2005. Forage mixture productivity and botanical composition in pastures grazed by dairy cattle. Agronomy Journal 97: 1465-1471.

Stewart, A.V. 1996. Plantain (Plantago lanceolata) a potential pasture species. Proceedings of the New Zealand Grassland Association 58: 77-86.

Tharmaraj, J.; Chapman, D.F.; Nie, Z.N.; Lane, A.P. 2008. Herbage accumulation, botanical composition, and nutritive value of five pasture types for dairy production in southern Australia. Australian Journal of Agricultural Research 59: 127-138.

Totty, V.K.; Greenwood, S.L.; Bryant, R.H.; Edwards
G.R. 2013. Nitrogen partitioning and milk production of dairy cows grazing simple and diverse pastures. Journal of Dairy Science 96: 141-149.

Vibart, R.E.; Vogeler, I.; Dodd, M.; Koolaard J. 2016. Simple versus diverse temperate pastures: Aspects of soil-plant-animal interrelationships central to nitrogen leaching losses. Agronomy Journal 108 2174-2188

Woodward, S.L.; Waugh, C.D.; Roach, C.G.; Fynn, D.; Phillips J. 2013. Are diverse species mixtures better pastures for dairy farming? Proceedings of the New Zealand Grassland Association 75: 79-84. 